\title{
Erratum to: Association between allelic variation at the Phytoene synthase 1 gene and yellow pigment content in the wheat grain
}

\author{
W. Zhang • J. Dubcovsky
}

Published online: 27 April 2011

(C) Springer-Verlag 2011

Erratum to: Theor Appl Genet (2008) 116:635-645

DOI 10.1007/s00122-007-0697-8

In the original version of Table 1, the primer sequence for primer PSY1_EF2 was incorrect. The correct primer sequence is CTACGTTGCGGGCACCGTT.

The online version of the original article can be found under doi:10.1007/s00122-007-0697-8.

W. Zhang · J. Dubcovsky $(\bowtie)$

Department of Plant Sciences, University of California,

One Shields Avenue, Davis, CA 95616, USA

e-mail: jdubcovsky@ucdavis.edu 